\title{
Reducing alcohol-related risks among adolescents: a feasibility study of the SHAHRP program in Brazilian schools
}

\author{
Redução de riscos relacionados ao uso de álcool entre adolescentes: \\ um estudo de viabilidade do programa SHAHRP em escolas \\ brasileiras
}

Tatiana de Castro Amato (https://orcid.org/0000-0002-1860-1010) ${ }^{1}$

Emérita Sátiro Opaleye (https://orcid.org/0000-0002-0676-7881) ${ }^{1}$

Nyanda McBride (https://orcid.org/0000-0003-1714-6631) ${ }^{2}$

Ana Regina Noto (https://orcid.org/0000-0003-2622-6668) ${ }^{1}$

${ }^{1}$ Núcleo de Pesquisa em Saúde e Uso de Substâncias, Departamento de

Psicobiologia, Universidade Federal de São Paulo. Rua Botucatu $8621^{\circ}$ andar, Vila Clementino. 04023 062 São Paulo SP Brasil. taticastroamato@gmail.com ${ }^{2}$ National Drug Research Institute, Curtin University. Perth WA Austrália.

\begin{abstract}
The SHAHRP program was effective reducing drinking and alcohol - harms in Australia, but cross-cultural adaptation is required before replication. This study aimed at assessing the feasibility of SHAHRP in Brazil focused on implementation and acceptability. A mixed-methodsdesign was used: quantitative for implementing the program and evaluation and qualitative for acceptability. The quantitative design was a pilot of a randomized controlled trial. Private schools were randomly divided into four intervention $(n=160)$ and four control $(n=188)$ schools. Student's mean age was 12.7 years. The fidelity of implementation and likely outcome measures were assessed. Qualitative data on acceptability were provided by students and teachers. The percentage of implementation varied from $62.5 \%$ to $87.5 \%$. Behaviours such as alcohol-harms requires a larger cohort and longer follow-up to be adequately evaluated. The risk reduction approach and activities had good acceptability from students and teachers. Quantitative and qualitative outcomes on knowledge and decision-making indicated possible improvement in SHAHRP schools. The program is feasible and well accepted in a Brazilian setting, opening the way for a more comprehensive evaluation and dissemination. Key words Alcohol drinking, Adolescent, Prevention, Risk reduction, Education
\end{abstract}

Resumo O programa SHAHRP foi eficaz na Austrália, mas precisa de adaptação transcultural para replicação em outro país. Este estudo teve como objetivo avaliar a viabilidade do SHAHRP no Brasil com base na sua implementação e aceitação. Utilizou-se métodos mistos: quantitativo para a implementação do programa e da avaliação e qualitativo para aceitação. O desenho quantitativo foi o piloto de um estudo clínico randomizado. Participaram escolas particulares: quatro intervenções $(n=160)$ e quatro controles $(n=$ 188). Os alunos tinham 12,7 anos em média. A fidelidade da implementação e possíveis medidas de resultados foram avaliadas. Os dados qualitativos sobre aceitação foram relatados por alunos $e$ professores. A fidelidade de implementação variou de $62,5 \%$ a $87,5 \%$. Comportamentos como danos causados pelo uso de álcool precisam de uma amostra maior e de mais tempo para avaliação. A abordagem de redução de riscos e as atividades do programa foram bem aceitas por alunos e professores. Os resultados quantitativos e qualitativos sobre conhecimento e tomada de decisão indicaram possivel melhora nas escolas-intervenção. $O$ programa é viável e bem aceito no cenário brasileiro, abrindo caminho para avaliação e disseminação mais abrangentes.

Palavras-chave Consumo de bebidas alcoólicas, Adolescente, Prevenção, Redução do dano, Educação 


\section{Introduction}

Initiation of alcohol use often occurs early in adolescence and is the most commonly used drug among adolescents in many countries ${ }^{1}$. In Brazil, it is illegal to sell or supply alcohol to anyone under the ages of 18 years, however this does not prevent adolescents obtaining and consuming al$\mathrm{cohol}^{2}$. About $60 \%$ of Brazilian students in public schools aged 13 to 15 years report ever having consumed alcohol, while in private schools prevalence of use is $70 \%{ }^{2}$. A third of Brazilian high school students had experienced at least one problem associated with alcohol use and a half of those who had drunk reported heavy episodic drinking the last 12 months $^{3}$. Another Brazilian study found that consumption is more prevalent in higher economic classes suggesting the link between access to alcohol, increased disposable income and wealth ${ }^{4}$.

Other behaviours that may put Brazilian adolescents at risk of harm have been identified. National data of students aged 13 to 15 years reported that $36 \%$ of boys and $19.5 \%$ of girls become sexually active during this period and almost $32.4 \%$ had illegally driven motor vehicles ${ }^{5}$. Often these behaviours are linked to alcohol use ${ }^{3}$. In addition to the likelihood of risk-taking behaviours, adolescents are also less likely to know how to protect them selves or make decisions that keep themselves safe in alcohol use situations ${ }^{6,7}$. Many adolescents incorrectly believe that strategies suchas ingesting caffeinated drinks, taking cold baths and eating sweetswill make them become sober $^{6,7}$. However, they are subsequently engaging in activities that put them at risk, believing that they are sober but while actually still under the influence of alcohol.

Alcohol consumption is a leading cause of premature death, illness and disability among adolescents ${ }^{1}$. This situation can however be amenable to preventive interventions. School is a highly suitable environment for the development of preventive programs in adolescence, ${ }^{8,9}$, and although some specific educational programs on alcohol and other drugs have shown effective results in changing the behaviours, beliefs and attitudes of adolescents, for the most part, the ability to produce behavioural change in relation to alcohol consumption and behaviours is less likely ${ }^{8,10}$.

Programs developed in the United States and Europe have been systematically evaluated for their impact on adolescent drug use'; however, most programs adopt an approach focused on ab- stinence from consumption ${ }^{11}$. Such an approach disregards the early onset and high prevalence of alcohol use among adolescents under 18 years of age $^{8,10}$. Programs with broader approaches which consider measures to reduce alcohol-related problems, attitudes, and risk behaviours related to the use of alcohol may be more effective ${ }^{8,12}$.

\section{The School Health and Alcohol Harm Reduction Project (SHAHRP)}

The School Health and Alcohol Harm Reduction Project (SHAHRP) was developed by researchers from the National Drug Institute at Curtin University, Australia ${ }^{13}$. The success of SHAHRP has been recognized through its acceptance by students and teachers, and in particular in its behavioural impact by reducing total alcohol consumption, risky alcohol consumption and alcohol-related problems in adolescence ${ }^{8,12,13}$. The harm reduction approach used by SHAHRP was effective in Australia, reducing alcohol related harm by $32.7 \%$ after the first phase of the SHAHRP program, $16.7 \%$ after the second phase of the SHAHRP program, and by $22.9 \%$ one year after program implementation had been completed $^{13}$. Although the reduction in alcohol use was not the main outcome of the program, the intervention students were $25.7 \%$ and $33 \%$ less likely to drink to risky levels after the first and second phases of the SHAHRP intervention ${ }^{13}$. A replication of the SHAHRP progam in Northern Ireland support these findings ${ }^{14}$.

The Australian SHAHRP program consists of eight weekly lessons lasting 60 minutes in the first phase of the program (year 8, 13 years of age), and five, 60 minutes lessons in the second phase of the program (year 9, 14 years of age $)^{13,15}$. Based on national prevalence data, the first phase of the program was provided in the year prior to widespread experimentation with alcohol, and the second phase during the year when a large proportion of adolescents start to experiment with alcohol. Each session comprised two to five different activities, with 29 activities in the whole program. The SHAHRP program was interactive, with $64 \%$ of activities having a primary emphasis on interaction and a further $15.4 \%$ of activities requiring some level of interaction between students. It included real-life situations experienced by students, delivery of useful knowledge, skill rehearsal, individual and small group decision making experience and discussions based on local students scenarios, with an emphasis on identifying alcohol-related harm 
The high prevalence of alcohol consumption by Brazilian adolescents combined withthe knowledge gaps on evaluation of preventive programs encourage the development and/or adaptations of potential programs in the Brazilian school setting. The positive results of SHAHRP, its acceptance by youth, and the altruistic free-ofcharge nature made the program a good choice to be adapted for use in Brazil. Across-cultural adaptation of the phase one of SHAHRP was made for private schools in São Paulo, named PERAE (Programa de Estímulo à Saúde e Redução de Riscos Associados ao Uso de Álcool Aplicado ao Ambiente Educacional). "PERAE" in Brazil is a colloquial abbreviation of the word "wait". It is a way of saying "wait" when we need a time to think and act.

To adapt programs evaluated as effective in other countries into a Brazilian setting, care must be taken to address terms of agreement between the stakeholders (school management, parents and students), and to assess their appropriateness to the culture and values of the population, as well as identifying knowledge about the processes underlying the behaviour of the adolescents, and their experiences and needs ${ }^{12,16}$. These steps are important to allow the program to meet the needs of the target population, which may be different from the population for which the program was originally developed.

The cross-cultural adaptation process of SHAHRP involved the translation of the first phase of Australian SHAHRP materials, and focus groups with Brazilian students in order to gather information on alcohol-related situations experienced by adolescents for inclusion in the PERAE materials. Brazilian education experts suggested adaptations to the student and teacher material to best suit the Brazilian culture and school setting, while maintaining the original, content as much as possible ${ }^{17}$.

Despite the positive results of the SHAHRP program, feasibility studies are lacking in Latin American countries with different languages and cultures ${ }^{14}$. In view of this, the aim of the present study was to assess the feasibility of the adapted SHAHRP program in Brazil. Feasibility studies evaluate processes and es-

tablish important parameters to guide program evaluation ${ }^{18,19}$. It is not concerned with rigorous outcome examination but assess whether an intervention has the potential to work ${ }^{18}$. It also focuses on the process of development and implementation of an intervention in the new context ${ }^{18,20}$. If a feasibility study is not undertaken in the new context, there is a greater chance of future research bias and compromised results.

\section{Methods}

\section{Study design}

This study was conducted with students aged 12-14 years from eighth-grade classes in private schools in São Paulo, Brazil. It was used a mixed methods design. Quantitative methods were to evaluate fidelity of the implementation (dose and reach), and were used to assess SHAHRP Australia impact measures to enable planning of effectiveness assessment in Brazil ${ }^{21}$. A pilot of a randomized controlled trial comparing pre and post-intervention groups of students from schools that received the PERAE program and students from the schools that did not (control) helped to provide guidelines for future effectiveness assessment.

Qualitative methods were used to assess the acceptability, appropriatness, utility and cultural adaptations. It was designed to incorporate consumer group (student and teacher) input to ensure that the program was usable and meaning-ful in the Brazilian context. Qualitative data was gathered via workshop with teachers who had implemented the PERAE program, and written feedback from students. Figure 1 shows a flowchart of the study.

\section{Quantitative: program implementation and the evaluation process}

\section{Procedures}

All students (intervention and control) completed a self-administered questionnaire in the classroom, one month before starting the program (baseline - T0)(Figure 1). Six months after the first session(T1), the students completed the same questionnaire.

The program was implemented by teachers who were either volunteers or designated by the school. Each class had a trained researcher present during the program sessions to collect 


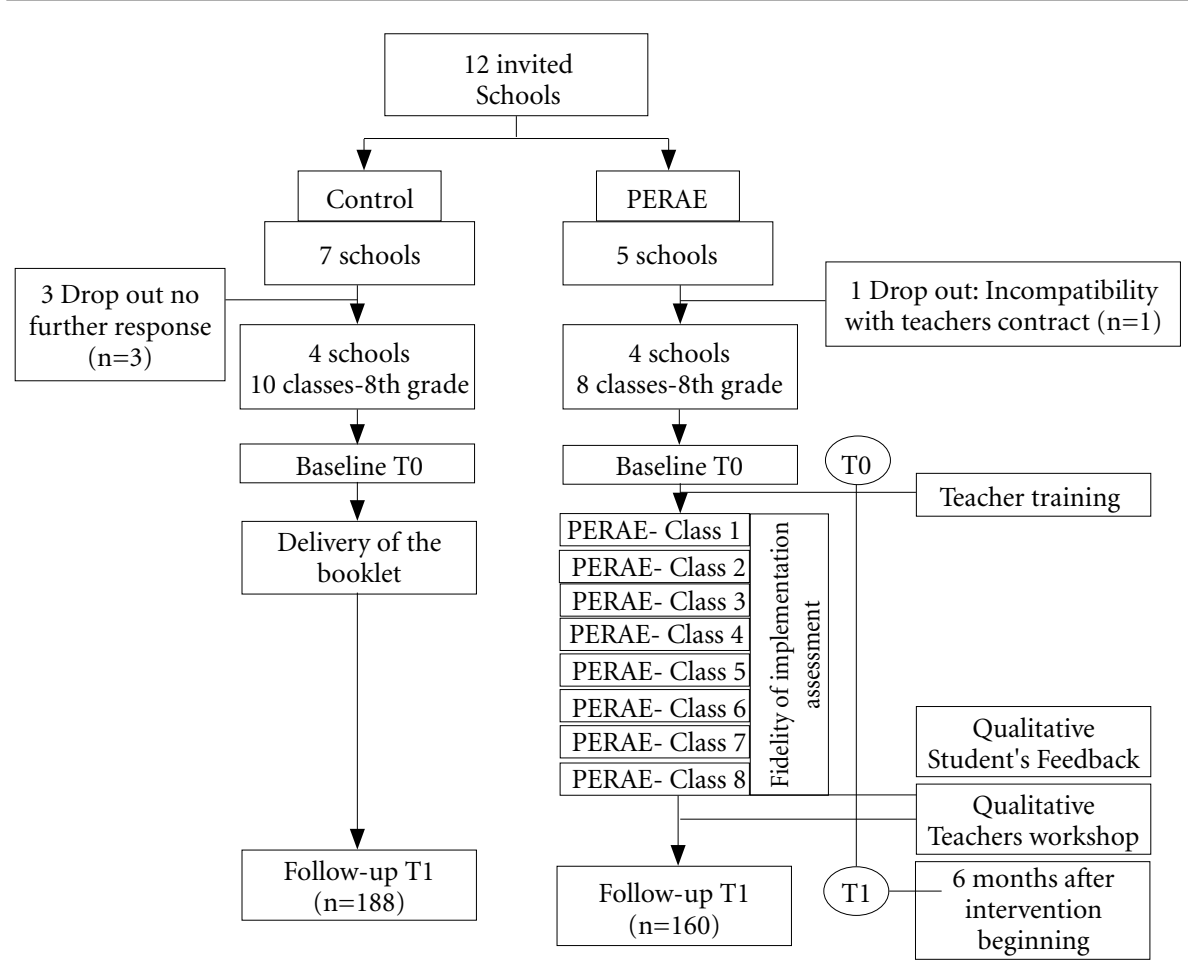

Figure 1. Study Design Diagram.

Source: Author's elaboration.

data on the fidelity of program implementation. All research occurred within usual class activities, according to the availability within each school. Control schools received an information booklet on alcohol, prepared by the National Secretariat for Drug Policy instead of PERAE.

The study was approved by the Research Ethics Committee of UNIFESP. The school principals and teachers signed free and informed consent form (FICF). Parental FICF was required for their child to be involved in the study. Teachers received US $\$ 215.00$ to reimburse them for the extra work and research activities.

\section{Participants}

Twelve schools were selected into the study based on their interest. To reduce sample bias, schools were stratified according to the city (São Paulo or Atibaia), approximate monthly tuition fee and the number of students at the school. They were divided into five groups: A) four schools with less than 500 students and monthly payments under 375 USD; B) two schools with be- tween 500 and 800 students and monthly fees of between 240 and 475 USD; C) two schools with between 800 and 1000 students and monthly fees of between 240 and 475USD; D) two schools with over 475 and monthly tuition above 950 USD; E) two schools from Atibaia formed another stratum. The intervention and control group were randomly drawn from within each stratum.

One of the original twelve schools refused the invitation and three did not respond to the invitation, leaving eight schools to take part in the study. Six schools were from São Paulo (one from group A, two from group B, one from group C, two from group D) and two from Atibaia (group E). Thus, the intervention and control groups had four schools each. All the eighth-grade classes of the intervention and control schools were included in the study.

\section{Response and attrition rate}

The response rate of parental consent forms was high ( $81 \%$ on average). In the control schools, $74 \%$ of the parents returned the FICF 
compared to $100 \%$ of PERAE schools. Both intervention and control consent groups had statistically similar characteristics in respect of age, gender and economic class.

A total of 410 students at T0 and 424 at T1 completed the questionnaire. The difference found in the number of respondents at T0 and T1 was due to the late return of the FICF. The questionnaires were coded for the pairing of T0 and T1. However, due to inconsistencies in some of the codes, there were a total of 366 paired questionnaires, of which 348 contained complete data for all the variables analysed.

\section{The PERAE program}

The PERAE program was delivered following the same structure reported for phase one of the original SHAHRP program ${ }^{15}$. As in Australia, teachers from PERAE schools completed a twoday training course $(16 \mathrm{~h})^{15}$. The training provided interactive modelling of each activity, with a presentation about the research, the components of the scientific evidence of the program and a guide to the activities.

\section{Quantitative data collection instruments}

\section{Fidelity of implementation}

Using the same measures for the fidelity of implementation as used by the Australian researchers, the Brazilian researchers who were in the classroom completed the "fidelity of implementation" measure ${ }^{22}$. This instrument made it possible to calculate the dose of the program provided by each teacher. For each activity, the researchers recorded whether it was completed, incomplete or not completed at all. The number of students receiving the intervention was also informed to determine the reach of the program.

\section{Baseline and follow-upmeasures}

The current study used the same instruments from Australian SHAHRP studies for the quantitative measures ${ }^{21}$. An English to Portuguese translation and back-translation, followed by a pilot study of the Brazilian version was conducted. The questionnaires were applied at T0 and $\mathrm{T} 1$ and were comprised of closed questions and evaluation scales, described below with their internal consistency (Cronbach's alpha).

Socioeconomic level: the Brazilian Criteria of Economic Classification allows classification of economic class from " $A$ " to " $E$ ", where " $A$ " is the highest level ${ }^{23}$.

Knowledge level: 19 statements related to alcohol consumption with responses true, false or do not know, e.g. Drinking strong coffee helps you sober up. The score was calculated from the number of correct responses, $(\alpha=0.64)$.

Alcohol use: lifetime, frequency and number of drinks ( 1 drink $=14 \mathrm{~g}$ of ethanol) in the last 6 months were assessed.

Decision-making skills: 20 statements in which the students had to rate their skills in making real-life decisions in situations involving alcohol and personal safety, e.g. Plan for safe travel to or from a party or gathering. Answers range from $0 /$ none to 3/a lot, $(\alpha=0.89)$.

Harm due to own consumption: 17 questions about the frequency in which personal harm related to alcohol consumption had occurred, e.g. In the last six months, how many times did you get into a fight with someone because you were under the effect of alcohol? Response options: never, once, twice, 3 or 4 times, 5 to 11 times, 12 times or more $(\alpha=0.92)$.

Harm due to the consumption of others: six questions similar to the aforementioned scale, but due to the alcohol use of others $(\alpha=0.52)$.

Beliefs about consequences of alcohol consumption: 14 questions, with response options ranging from 0 (totally disagree) to 4 (totally agree). The score can be evaluated for negative $(\alpha=0.88)$ and positive $(\alpha=0.83)$ consequences $^{24}$.

\section{Quantitative data analysis}

Data was dually-entered into the database to minimize errors, and reviewed before analysis to eliminate inconsistencies in responses. All analyses were performed using the statistical program SPSS Version 18, adopting a level of significance of 5\%. Bivariate descriptive and exploratory analyses were performed to assess differences between PERAE and control groups at the baseline. To assess the differences between categorical variables, Chi-square tests were used, and for numerical variables, means were compared using Student's t-test. Groups were compared for each parameter, using Analysis of Variance (ANOVA) with repeated measures with fixed factor (group) and interaction (group $\mathrm{x}$ time) using the Generalized Linear Model (GLM). As recommended in pilot studies for planning a randomized controlled trial, statistical analysis were exploratory since no formal power calculation have been carried out ${ }^{19}$. 


\section{Qualitative: acceptability from students and teachers}

The qualitative study included both feedback from teachers and students about the acceptability of PERAE.

\section{Qualitative data}

Feedback from students: After the final lesson of the program, the students completed a self-administered questionnaire that included three open questions: 'what did you like about PERAE,?' 'what did you not like about PERAE?' and 'what would you change?. This questionnaire took about 20 min for students to complete (the teacher and a researcher were present). A total of $142(60 \%)$ of students answered the questionnaire. The $40 \%$ of students who did not complete the feedback were absent from school on the day of data collection.

Teacher evaluation workshop: The workshop schedule addressed the implementation process of PERAE and was conducted post delivery with particular emphasis on 1) the adequacy of the time for the classes and activities, and 2) the teachers' opinions about the risk reduction approach. The teacher evaluation workshop took place at the University and lasted about 80 minutes. Two researchers conducted the group, one as a facilitator and the other as an observer. Both had experience in qualitative research methodologies. The workshop was audio recorded and later transcribed. Four of the six teachers who taught the program participated (three women and one man), aged between 30 and 34 years. The teachers had a diverse background: biology teacher, a math teacher, a pedagogue and a psychologist. The two teachers who did not attend were from the same school, one was not available and the other was on maternity leave.

\section{Qualitative data analysis}

The data were analysed with Nvivo 10, using the content analysis technique ${ }^{25}$. The themes for the analysis were pre-defined in the construction of the questionnaires which were declared in the qualitative data section. The categories that emerged from the analyses were checked by two researchers.

\section{Results}

Following the same structure presented in our methods, we present our findings in two sections: first quantitative data followed by the qualitative data one.

\section{Quantitative}

\section{Fidelity of implementation}

Table 1 presents the fidelity of implementation, including the dose and the reach of the program. All the eight classes received the eight lessons as planned, however, there was some variation as to how faith fully the teachers implemented the activities according to the instructions in the teacher manual. In one of the classes, only $21.7 \%$ of the program was implemented, for this reason, this group $(\mathrm{N}=18)$ was considered missing data, and was excluded from all analyses that compared PERAE and control groups. According to the field diary notes, the teacher did not prepare the classes but rather offered students her own opinion on alcohol use.

On average, $72,3 \%$ of the activities were carried out as recommended in the teacher's manual, excluding the cases cited above. However, if all eight classes are included, the fidelity of implementation attains $66,8 \%$. The percentage of complete lessons implemented varied from $62,5 \%$ to $87,5 \%$ (Table 1 ). Some adaptation of the activities occurred, and when this occurred, activities were considered incomplete. The primary justification for adaptation was time constraint and for the same reason, some other activities were not implemented.

\section{Characteristics of students}

The questionnaire from 348 students were analysed, 188 from the control group and 160 from the intervention (PERAE) group. Both groups had statistically similar characteristics in respect of age, gender and economic class (mean age: control 12.7 [ $\mathrm{SD}=0.5]$, intervention group $12.7[\mathrm{SD}=0.6]$; gender: control group female $46.8 \%$, intervention group 50\%; ABEP scale for economic class: control group $69.8 \%$ of students were in class $\mathrm{A}, 19.5 \%$ in class $\mathrm{B} 1,10.1 \%$ in class $\mathrm{B} 2$ and $0.6 \%$ in classes $\mathrm{C}, \mathrm{D}$ and $\mathrm{E}$; intervention (PERAE) $65.5 \%$ of students in class A, $18.2 \%$ in class B1, $13.5 \%$ in class B2 and $2.7 \%$ in classes $C$, $\mathrm{D}$ and $\mathrm{E})$. 


\section{Possible outcome measures: comparisons between baseline (T0) and follow-up (T1)}

The control and PERAE groups were compared to assess possible baseline differences for all measures. The only significant difference at baseline was found in relation to "lifetime use", with the PERAE group presenting a prevalence of consumption approximately $10 \%$ higher than the control group $(\mathrm{p}=0.039)$ (Table 2). Longitudinal analysis included seven PERAE classes.

After the intervention, students who completed the PERAE program had better knowledge and decision-making skills than students

Table 1. Quality of implementation of the PERAE program in four private schools.

\begin{tabular}{cccccrrr}
\hline \multicolumn{7}{c}{ Programme Dosage } & \multicolumn{3}{c}{ Fidelity of Implementation } \\
\hline Sessions & $\begin{array}{c}\text { Total of } \\
\text { planned } \\
\text { activities } \\
(\mathbf{n})\end{array}$ & $\begin{array}{c}\text { Incomplete } \\
\text { activities } \\
(\mathbf{n})\end{array}$ & $\begin{array}{c}\text { Not } \\
\text { performed } \\
\text { activities } \\
(\mathbf{n})\end{array}$ & $\begin{array}{c}\text { Complete } \\
\text { lessons } \\
(\%)\end{array}$ & Activity full delivered (\%) & $\begin{array}{c}\text { Attendance } \\
(\mathbf{n})\end{array}$ & $\begin{array}{c}\text { Reach } \\
(\%)\end{array}$ \\
\hline 1 & 40 & 6 & 6 & $70,0 \%$ & $1(87.5), 2(87.5), 3(75)$, & 202 & 85,6 \\
& & & & & $4(75), 5(25)$ & & \\
2 & 16 & 2 & 0 & $87,5 \%$ & $1(87.5), 2(87.5)$ & 203 & 86,0 \\
3 & 24 & 8 & 3 & $54,2 \%$ & $1(75), 2(62.5), 3(25)$ & 205 & 86,9 \\
4 & 40 & 8 & 8 & $60,0 \%$ & $1(75), 2(87.5), 3(75), 4$ & 205 & 86,9 \\
& & & & & $(50), 5(12.5)$ & & \\
5 & 24 & 8 & 0 & $66,7 \%$ & $1(87.5), 2(62.5), 3(50)$ & 206 & 87,3 \\
6 & 16 & 3 & 1 & $75,0 \%$ & $1(87.5), 2(62.5)$ & 205 & 86,9 \\
7 & 24 & 8 & 2 & $58,3 \%$ & $1(50), 2(75), 3(50)$ & 193 & 81,8 \\
8 & 24 & 2 & 7 & $62,5 \%$ & $1(87.5), 2(50), 3(50)$ & 155 & 65,7 \\
\hline
\end{tabular}

Source: Author's elaboration.

Table 2. Comparison of the possible outcome indicators in the control and PERAE groups at T0 and T1 ${ }^{\text {a }}$.

\begin{tabular}{|c|c|c|c|c|c|c|}
\hline & & \multicolumn{2}{|c|}{ Control $(n=188)$} & \multicolumn{2}{|c|}{ PERAE $(n=160)$} & \multirow[t]{2}{*}{ p } \\
\hline & & T0 & $\mathrm{T} 1$ & T0 & $\mathrm{T} 1$ & \\
\hline \multicolumn{7}{|l|}{ Alcohol } \\
\hline \multirow[t]{3}{*}{ Ever used } & & n (\%) & n (\%) & n (\%) & n $(\%)$ & \\
\hline & No & $61(32.4)$ & $54(28.9)$ & $36(22.5)$ & $33(21.0)$ & $0.039^{\star}$ \\
\hline & Yes & $127(67.6)$ & $133(71.1)$ & $124(77.5)$ & $124(79)$ & \\
\hline \multicolumn{7}{|c|}{ Use in the last 6 months } \\
\hline & No & $106(58.6)$ & $104(55.6)$ & $76(49.4)$ & $70(45.5)$ & $>0.050^{\mathrm{b}}$ \\
\hline \multirow{2}{*}{\multicolumn{2}{|c|}{ Yes }} & $75(41.4)$ & $83(44.4)$ & $78(50.6)$ & $84(54.5)$ & \\
\hline & & Mean (SD) & Mean (SD) & Mean (SD) & Mean (SD) & \\
\hline \multicolumn{2}{|c|}{$\begin{array}{l}\text { Number of drinks in the last } 6 \\
\text { months }\end{array}$} & $2.0(9)$ & $2.2(6.6)$ & $3.0(11.3)$ & $4.1(15.5)$ & 0.930 \\
\hline \multicolumn{2}{|c|}{ Knowledge level } & $19.5(4.9)$ & $20.0(6.0)$ & $18.2(5.5)$ & $22.0(6)$ & $0.000^{\star *}$ \\
\hline \multicolumn{2}{|l|}{ Decision making skills } & $46.6(10.1)$ & $44.2(9.6)$ & $45.0(11.4)$ & $47.2(11.3)$ & $0.003^{\star *}$ \\
\hline \multicolumn{7}{|c|}{ Beliefs about consequences } \\
\hline \multicolumn{2}{|c|}{ Positive } & $9.3(5.2)$ & $10.3(5.4)$ & $10.0(4.9)$ & $10.6(6.0)$ & 0.583 \\
\hline \multicolumn{2}{|l|}{ Negative } & $18.0(8.4)$ & $15.8(8.0)$ & $16.2(7.8)$ & $15.2(8.3)$ & 0.358 \\
\hline \multicolumn{2}{|l|}{$\begin{array}{l}\text { Harm due to own } \\
\text { consumption }\end{array}$} & $0.5(3.2)$ & $0.6(3.1)$ & $0.8(2.7)$ & $1.4(3.8)$ & 0.242 \\
\hline \multicolumn{2}{|l|}{$\begin{array}{l}\text { Harm due to the } \\
\text { consumption of others }\end{array}$} & $1.5(2.5)$ & $1.5(2.9)$ & $1.6(2.5)$ & $1.7(2.6)$ & 0.868 \\
\hline
\end{tabular}


in the control group (Table 1). There were no other significant differences between intervention and control groups. A separate analysis was performed to assess whether students who had never used alcohol before baseline (T0) had used it by the time of the follow-up (T1). The difference was not significant $(p=0.791)$. Among those who reported not having ever used alcohol at baseline (PERAE $\mathrm{n}=36$; Control $\mathrm{n}=61$ ), a similar percentage of students did so in the group that received PERAE $(22.2 \%)$, and in the control group $(24.6 \%)$ at follow-up.

\section{Qualitative}

\section{Feedback from students}

The following student $(n=142)$ responses were received for each of the three themes noted below and in Chart 1. Most students expressed no need for changes to the content or delivery of the PERAE program.

In the theme 1, "What I liked", students reported having learned things that they thought would be important to use in practice ("useful knowledge"), that is, the learning seems to have been useful. The students highly valued increased knowledge on the risks of alcohol consumption and how to deal with risk situations. The most valued topics were related to "alcohol content and standard drinks". They also mentioned the deconstruction of myths about drinking and low-risk drinking as useful information. As for "class dynamics", there were positive reports about working in small groups and about the dialogue based on real situations of alcohol use.

In theme 2, "What I did not like" some students found some "lessons boring", especially when it was necessary to write or do individual activities.They felt there was not enough time and would like to know more about alcohol, while others found the "content repetitive". One of the schools implemented the "program in physical education classes" and the students were unhappy about this, although they liked the program.

In theme 3 "I suggest including' studentssuggested the inclusion of "more practical activities", such as games, activities, and group

Chart 1. Feedback from students regarding the PERAE acceptability $(\mathrm{N}=142)$.

\begin{tabular}{|c|c|c|}
\hline $\begin{array}{c}\text { Theme } 1 \\
\text { What I liked }\end{array}$ & $\begin{array}{c}\text { Theme } 2 \\
\text { What I did not like }\end{array}$ & $\begin{array}{c}\text { Theme } 3 \\
\text { What else I suggest including }\end{array}$ \\
\hline Useful knowledge & Repetitive content & $\begin{array}{l}\text { More time per class and more } \\
\text { classes }\end{array}$ \\
\hline $\begin{array}{l}\text { "The knowledge of the harm that drink can } \\
\text { do not only to me but also to other people" } \\
\text { "I learned to make the right decisions (not } \\
\text { that I wanted to smoke or drink)" }\end{array}$ & $\begin{array}{l}\text { "The repetitive subject of all } \\
\text { the classes" } \\
\text { "Too fast, too few lessons" }\end{array}$ & $\begin{array}{l}\text { "More classes for us to learn more" } \\
\text { "More time for activities" }\end{array}$ \\
\hline Alcohol content and standard drinks & Boring Lessons & More practical activities \\
\hline $\begin{array}{l}\text { "Knowing how much is a standard drink } \\
\text { and being able to warn people who are } \\
\text { going to drive" } \\
\text { "Interesting things, myths, facts, alcohol } \\
\text { content, amount of standard drink" } \\
\text { "Getting more knowledge and learning } \\
\text { about moderate alcohol consumption" }\end{array}$ & $\begin{array}{l}\text { "Not having enough } \\
\text { "practical" classes such as } \\
\text { measuring the quantity of } \\
\text { alcohol in each drink" } \\
\text { "Individual written } \\
\text { ctivities" } \\
\text { "Some classes were boring } \\
\text { and tiring" }\end{array}$ & $\begin{array}{l}\text { "They could have more fun } \\
\text { activities to help us to learn" } \\
\text { "More games about situations that } \\
\text { happen to those who drink" } \\
\text { "Situations of people who drank } \\
\text { alcohol and who did not, to learn } \\
\text { more about this" }\end{array}$ \\
\hline Classes dynamics & $\begin{array}{c}\text { Program in physical } \\
\text { education classes }\end{array}$ & $\begin{array}{c}\text { Knowing about subjects } \\
\text { not addressed }\end{array}$ \\
\hline $\begin{array}{l}\text { "Discussing situations related to alcoholic } \\
\text { drinks with friends, knowing each other's } \\
\text { opinion" } \\
\text { "Different games and ways to understand } \\
\text { this" } \\
\text { "Games, activities, videos, discussions" } \\
\text { "Groups, collective activities" } \\
\text { "Calculating the alcohol content in bottles" }\end{array}$ & $\begin{array}{l}\text { "The class is good but I did } \\
\text { not like missing my physical } \\
\text { education classes" }\end{array}$ & $\begin{array}{l}\text { "About illegal drugs" } \\
\text { "More about varying individual } \\
\text { alcohol metabolism" } \\
\text { "A role-play about accidents" } \\
\text { "Know about alcohol content of } \\
\text { other alcoholic drinks" } \\
\text { "How to treat your friends in } \\
\text { extreme cases" }\end{array}$ \\
\hline
\end{tabular}

Source: Author's elaboration. 
discussions, which were considered fun by the students. Among the requests were ones for more real-life situations that happen with those who do and do not drink. Students also asked for the inclusion of more in-depth study of alcohol metabolism, different types of alcoholic beverages, and issues related to the law. They also expressed interest in "knowing about other subjects not addressed", such as other drugs, and how to deal with accidents and addiction. The inclusion of "more time per class and more classes" was also requested.

\section{Teacher evaluation workshop}

According to the four teachers' experience, the main "difficulty" in relation to implementation was "lack of time" (Chart 2 - theme 1). Many activities had to be ended before the teachers felt that there had been enough discussion and two "solutions" were suggested. One would be to use two consecutive lessons totalling one hundred minutes. Another would be to extend the program to 10 classes to give teachers more freedom to spend time on activities that students would like more.

In respect of the "risk reduction" approach (theme 2), teachers said that it was difficult to change from the method they had previously used (abstinence). Self-monitoring was required. They had to remember that the program was designed to help students make their own decisions more safely. On the other hand, the teachers felt that they had a better relationship with their students and this generated more openness and less resistance in the classroom. According to the teachers, the "program approach" (theme 3 ) encouraged the students to provide their perspective on the subject,increasing their interest and involvement in the PERAE. The use of the third person to tell real-life stories also helped the discussion without the need to disclose personal information.

\section{Discussion}

The findings of this study reveal coherence between qualitative and quantitative data support-

Chart 2. Teacher evaluation workshop $(\mathrm{N}=4)$.

\begin{tabular}{|c|c|c|}
\hline $\begin{array}{c}\text { Theme } 1 \\
\text { Lack of time }\end{array}$ & $\begin{array}{c}\text { Theme } 2 \\
\text { Risk reduction }\end{array}$ & $\begin{array}{c}\text { Theme } 3 \\
\text { Program aproach }\end{array}$ \\
\hline $\begin{array}{l}\text { Solution } \\
\text { "I think increasing the number of } \\
\text { classes from } 8 \text { to } 10 \text { could dilute } \\
\text { some activities within that class." }\end{array}$ & $\begin{array}{l}\text { "Wow, I don't know if I will be able } \\
\text { to do this. But they saw that at no } \\
\text { time did I say, "don't drink". I felt } \\
\text { that the students became more } \\
\text { critical about alcohol } \\
\text { consumption" }\end{array}$ & $\begin{array}{l}\text { "In the program (...) at the } \\
\text { beginning, the teacher makes } \\
\text { an agreement with the students. (...) } \\
\text { Look, what we say here is going } \\
\text { to stay inside this room, it doesn't } \\
\text { matter to us to know who did what } \\
\text { or why, we will just discuss and } \\
\text { think about the stories that come } \\
\text { up. So that, at least in our school, } \\
\text { this gave us a good openness and } \\
\text { the students made use of it" }\end{array}$ \\
\hline $\begin{array}{l}\text { "We had the opportunity in the } \\
\text { last session do a double lesson, so I } \\
\text { spent } 100 \text { minutes with them. } \\
\text { That was great..." }\end{array}$ & $\begin{array}{l}\text { "It's a gamble that they can make } \\
\text { good decisions, isn't it? I think the } \\
\text { school, in general, has a hard time } \\
\text { believing they are able to" }\end{array}$ & $\begin{array}{l}\text { "It motivated discussion about the } \\
\text { subject, and the material helped to } \\
\text { make a good, interesting class that } \\
\text { they liked, which I think is the main } \\
\text { point, right?" }\end{array}$ \\
\hline $\begin{array}{l}\text { Difficulty } \\
\text { "Time was really the most difficult } \\
\text { factor. Sometimes you needed to } \\
\text { stop the activity because you could } \\
\text { not finish it, although you could } \\
\text { see that the students wanted to } \\
\text { continue" }\end{array}$ & $\begin{array}{l}\text { "(...) I know other programs that } \\
\text { just say, 'no, you can do that'. That's } \\
\text { why young people feel more } \\
\text { respected when you talk about } \\
\text { risk reduction! 'Look, I'm giving } \\
\text { you the option to think. I believe } \\
\text { you are able to consider this.' (...) } \\
\text { Students feel more respected and } \\
\text { I think that's why it gets through } \\
\text { better" }\end{array}$ & \\
\hline
\end{tabular}


ing the feasibility of the Brazilian version of the SHAHRP program (PERAE). The quantitative fidelity of implementation results indicate that the majority of the program could be maintained and that the program could be incorporated into the school timetable. Quantitative data also supported the conduct of future effectiveness studies with refinements to logistics around the informed consent form and method. The students and teachers reported good acceptability of the program. The students reported enjoying the main elements of the program, such as the interactive activities based on real-life experiences, as well as the risk reduction approach.Likewise, teachers highlighted that the program was a promising alcohol education resource, that the approach generated openness and respect between teachers and students, and some change to program timing would fit into the school's curriculum.

This is the first replication study of the SHAHRP program in the American continent and in a different language from the original (English). The program has previously been replicated outside of Australia, in Northern Ireland ${ }^{14}$, and in the United Kingdom (Ireland/Scotland ${ }^{26}$. The Northern Ireland study showed the applicability of the harm reduction approach with significant impact on alcohol use and the alcohol-related harm/risk ${ }^{14}$. The United Kingdom study reported significant impact on heavy episodic drinking for baseline drinkers and baseline non-drinkers, and significant reduction in alcohol related-harm in students who had consumed alcohol ${ }^{26}$. Our results show that this innovative program is well accepted in a Brazilian setting, providing an opportunity for its dissemination in countries with large cultural differences.

The $72 \%$ of full implementation of the program was a positive finding and comparable to $80 \%$ for the trial in Australia, considering that each lesson in Brazil is an average 10 minutes shorter than in Australia ${ }^{13,22}$. In addition to the high attendance of students, the quality of implementation was good. However, time constraint was considered a critical issue by teachers, compromising the quality of the discussion. Thus, adaptations need to be made, possibly reducing the number of activities per class (maximum three per class), since increasing the workload may jeopardize the dissemination of the program. However, if cuts to the program were to occur, consideration needs to be given to any impact that this may have on behavioural effects of the program. Another important issue is the adhesion of teachers to the risk reduction ap- proach. Given past emphasis on abstinence in alcohol education in Brazil, it may be necessary to select teachers with a profile supportive of alcohol harm reduction education to optimise implementation.

The adapted version of Unplugged program for Brazil (\#Tamojunto) had 57\% of classes implemented as recommended and a randomized clinical trial showed negative results for alcohol use $^{27,28}$. Some possible explanations for the $30 \%$ increased risk of initiating alcohol use among students who received the program were the lack of time to deliver its twelve classes, some adaptations in the material on alcohol consumption content and a boomerang effect on the program's message ${ }^{28}$.

One of the main criticisms of the risk reduction approach is the concern that giving adolescents information before the exposure to alcohol might encourage them to try $\mathrm{it}^{29}$. Considering the history of replication of the SHAHRP study and the indicators of lifetime alcohol use of this research, the program does not appear to have the potential to stimulate the consumption of alcohol among those who had not previously used it. The original SHAHRP researchers propose that there is an element of social innoculation that occurs when students are exposed to harm reduction education when it is provided immediately prior to an increase in the behaviour as indicated by prevalence data ${ }^{15}$. In the Brazilian context, it would be beneficial an investigation with a larger sample using the both phases of the SHAHRP program to test this hypothesis.

Additionally, according to the qualitative data about the students' own perception, and consistent with the quantitative findings, the PERAE program appears to increase the level of useful information the students had about harm reduction thereby increasing their decision-making capacity and ability to develop strategies to reduce the risks of alcohol consumption. Both decision-making and strategies of risk reduction are considered important mediating variables in the future reduction of alcohol consumption and harms ${ }^{30}$.

It is important therefore to underline how important it is for preventive programs to reflect the real-life situations of the young people and for their opinion to be heard, valued ${ }^{16,31}$ and included in preventive programs ${ }^{13}$. A risk reduction approach might be the preference of youth from different countries ${ }^{6,7,31}$ and this is reinforced in the opinions expressed by the students of thisstudy. 
The PERAE teachers welcomed the idea of investing in the potential of the students to make autonomous decisions. As some of the teachers remarked, schools have difficulty putting faith into the students' ability to make good choices. Educational models simply focused on the transmission of content have a long history of been called into question. Programs that help to develop critical thinking, promote problem-solving skills and lifelong learning autonomy ${ }^{32}$ are more effective and in this respect, PERAE offers a useful tool to foster change in teaching methods which are currently being questioned in Brazil.

\section{Learning from implementation for future evaluation studies}

As one of our aims, this feasibility study permitted the fine tuning of several aspects of our methodology for planning the effectiveness assessment. There is limited scope to assessing change in behaviours with low prevalence behaviour (e.g. harms due to alcohol use) within a six month period, more extended assessment periods which extend into a time when prevalence increases is required. A larger cohort will allow more rigorous statistical analysis which will take into account any baseline differences between the intervention and control groups and provide a clearer understand of the impact of the program. Lower rates of active parental consent in the control school may benefit from additional teacher reminders and research presentations/meetings to increase the active consent rate, or alternatively these types of studies may benefit from the use of passive parental consent. The Belief About Consequence Scale can be better tailored to Brazilian students experience and more development of this scale for the Brazilian context is required.

This study was not designed to evaluate the effectiveness and the interpretation of the results needs caution due to some limitations. The PERAE used only one phase of the SHAHRP program, and this likely reduced the potential for behavioural impact. The schools were recruited by convenience sampling, and the intervention and control groups had different patterns of alcohol consumption at baseline. The control group had a lower level of parental consent which may have resulted in these lection of a specific youth profile than that of the intervention group. Given these findings, it is reasonable to propose a large scale effectiveness study of PERAE in a cluster randomized controlled trial to generate clear evidence of its impact on alcohol consumption and alcohol-related risk and harm in Brazilian youth.

\section{Conclusion}

The results of the feasibility study are promising and indicate that it would be worthwhile to conduct an effectiveness study of PERAE/SHAHRP program in educational settings in Brazil with larger samples using a cluster randomized controlled trial. Few adaptations on phase one are necessary and a cross-cultural adaptation of phase two is recommended for broader dissemination in Brazil. The program received a positive response from the students, and seems to result in changes in utility knowledge and decision-making skills around alcohol which may provide to be critical skills in alcohol use situations as alcohol use becomes more prevalent in later teen years. The results suggest good acceptance of the program in a different cultural setting from that it was initially developed, which may encourageits use in other low and middle-income countries.

The evaluation of preventive programs for substance use in Brazil is in its infancy. This is the first study in Latin America to use the SHAHRP program, an evidence-based intervention to reduce risky drinking and alcohol-related harm among adolescents applied in schools. Following what is methodologically recommended in the literature, this study brings a fundamental contribution and maturity to the evaluation practice regarding risk reduction approaches in Brazil, especially considering the established cultural norms of prevention approach focused only on abstinence from consumption. Considering the outcomes of this study, this is a promising intervention that enthusiasm researchers to develop the next steps of the evaluation of the program in Brazil. 


\section{Collaborations}

TC Amato did the data collection, the analysis and wrote the first version of the article. ES Opaleye, $\mathrm{N}$ McBride and AR Noto participated actively in the research design, analysis and discussion of the results. All authors participated in the review and approval of the final version of the paper.

\section{Acknowledgements}

Special thanks to the NDRI (Curtin University) who authorized the adaptation of the SHAHRP program to Brazil. Thanks to the Brazilian team that worked to adapt the first phase of the program: André Bedendo, Carla Regina Zuquetto, Danilo Polverini Locatelli, Larissa Padovez Gonçalves, Maria Helena Pagdi, Mayra Pires Alves Machado e Waldir Hernandes.

\section{Funding}

This project was supported by FAPESP, CNPq and with financial support from AFIP (Fund for Research Incentive), PhD scholarship from CAPES and FAPESP. The funding agencies had no role in the design of the study and collection, analysis, and interpretation of data and in writing the manuscript. 


\section{References}

1. Wold Health Organization (WHO). Global status report on alcohol and health 2018. Switzerland: WHO; 2018.

2. Carlini EA, Noto AR, Sanchez ZM, Carlini CMA, Locatelli DP, Abeid LR,Amato T C, Opaleye ES, Tondowski CS, Moura YG. VI Levantamento Nacional sobre o Consumo de Drogas Psicotrópicas entre Estudantes do Ensino Fundamental e Médio das Redes Pública e Privada de Ensino nas 27 Capitais Brasileiras. São Paulo: Centro Brasileiro de Informações sobre Drogas Psicotrópicas; 2010.

3. Gomes K, Amato TC, Bedendo A, Santos EL, Noto AR. Problems related to binge dinking among studentsBrazilian's state capitals. Cien Saude Colet 2019; 24(2):497-507.

4. Locatelli D, Sanchez Z, Opaleye E, Carlini C, Noto A. Socioeconomic influences on alcohol use patterns among private school students in Sao Paulo. Rev Bras Psiquiatr 2012; 34(2):193-200.

5. Instituto Brasileiro de Geografia e Estatística (IBGE). Pesquisa Nacional de Saúde do Escolar 2015. Rio de Janeiro: IBGE; 2016

6. Farringdon F, Mcbride N, Midford R. The fine line: students' perceptions of drinking, having fun and losing control. Youth Stud Aust 2000; 19(3):32-18.

7. Gonçalves LP, Opaleye ES, Amato TC. Percepção de riscos e estratégias de redução de danos do uso de álcool por adolescentes: subsídios para intervenções além do “diga não". Brasília: SENAD/CIEE.;2014.

8. Babor TF, Caetano R, Casswell S, Edwards G, Giesbrecht N, Graham K, Grube JW, Hill L, Holder H, Homel R, Livingston M, Österberg E, Rehm J, Room R, Rossow I. Alcohol: No Ordinary Commodity. Research and Public Policy. 2a ed. New York: Oxford University Press;2010.

9. Shackleton N, Jamal F, Viner RM, Dickson K, Patton G, Bonell C. School-Based Interventions Going Beyond Health Education to Promote Adolescent Health: Systematic Review of Reviews. J Adolesc Health 2016; 58:382-396.

10. McBride N. The evidence base for school drug education interventions. In: Stockwell T, Gruenewald P, Toumbourou J, Loxley W editors. Preventing Harmful Substance Use: The evidence base for policy and practice.UK: Wiley;2005.

11. Midford R. Drug prevention programmes for young people: where have we been and where should we be going? Addiction 2010; 105(10):1688-1695.

12. Cahill HW. Challenges in adopting evidence-based school drug education programmes. Drug Alcohol Rev 2007; 26(6):673-679.

13. McBride N, Farringdon F, Midford R, Meuleners L, Phillips M. Harm minimization in school drug education: final results of the School Health and Alcohol Harm Reduction Project (SHAHRP). Addiction 2004; 99(3):278-291.

14. Mckay M, NT. M, Sumnall H, Cole JC. Reducing the harm from adolescent alcohol consumption: results from an adapted version of SHAHRP in Northern Ireland. J Subs Use 2012; 17(2):98-121.
15. McBride N, Farringdon F, Muleners L, Midford R. School Health and Alcohol Harm Reduction Project. Details of intervention development and research procedures. Perth, Western Australia: National Drug Research Institute, Curtin University;2006.

16. Gosin MN, Dustman PA, Drapeau AE, Harthun ML Participatory Action Research: creating an effective prevention curriculum for adolescents in the Southwestern US. Health Educ Res 2003; 18(3):363-379.

17. Noto AR, Amato TC. PERAE - SHAHRP Brasil - redução de riscos associados ao álcool In: Diehl A, Figlie NB, editors. Prevenção ao Uso de Álcool e Drogas: O Que Cada Um de Nós Pode e Deve Fazer? Porto Alegre: Artmed;2014.

18. Orsmond GI, Cohn ES. The Distinctive Features of a Feasibility Study: Objectives and Guiding Questions. OTJR 2015; 35(3):169-177.

19. Lancaster GA, Dodd S, Williamson PR. Design and analysis of pilot studies: recommendations for good practice. J Eval Clin Pract 2004;10(2):307-312.

20. Bowen DJ, Kreuter M, Spring B, Cofta-Woerpel L, Linnan L, Weiner D, Bakken S, Kaplan CP, Squiers L, Fabrizio C, Fernandez M. How we design feasibility studies. A J Prev Med 2009; 36(5):452-457.

21. McBride $\mathrm{N}$. The assessment phase of the Intervention Research Framework: The measurement instrument and data collection.In:Intervention Research: A practical guide for developing evidence-based school prevention programs. Singapore: Springer; 2016.

22. McBride N, Farringdon F, Midford R. Implementing a school drug education programme: Reflections on fidelity. Int J Health Promot Educ 2002; 40(2):40-50.

23. Associação Brasileira de Empresas de Pesquisa (ABEP). Critério de Classificação Econômica Brasil [Internet]. 2008 [acessado 2010 jan 20]. Disponível em: wwwabeporg/codigosguias/Criterio_Brasil_2008pdf.

24. EMCDDA. Evaluation Instruments Bank (EIB) [Internet]. 2011 [cited 2010 Jan 20]. Available from: http:// www.emcdda.europa.eu/eib.

25. Bardin L. Análise de Conteúdo. 4a ed. Lisboa: Edições 70;2009.

26. Sumnall H, Agus A, Cole J, Doherty P, Foxcroft D, Harvey S, McKay M, Murphy L, Percy A. Steps Towards Misuse Prevention Programme (STAMPP): a school-and community-based cluster randomised controlled trial. Public Health Research 2017; 5(2).

27. Medeiros PF, Cruz JI, D RS, Sanudo A, Sanchez ZM. Process evaluation of the implementation of the Unplugged Program for drug use prevention in Brazilian schools. Subst Abuse Treat Prev Policy [periódico na Internet]. 2016 [acessado 2010 jan 10]; 2016;11(2):[cerca de 20 p.].Disponível em: https:// doi.org/10.1186/s13011-015-0047-

28. Sanchez ZM, Valente JY, Sanudo A, Pereira APD, Cruz JI, Schneider D, Andreoni S. The \#tamojunto drug prevention program in brazilian schools: a randomized controlled trial. Prev Sci 2017; 18(7):772-782.

29. Werch CE, Owen DM. Iatrogenic effects of alcohol and drug prevention programs. J Stud Alcohol 2002; 63(5):581-590. 
30. Gormana DM, Conde E. The making of evidence-based practice: the case of project ALERT. Child Youth Serv Rev 2010; 32(2):214-222.

31. Slemon A, Jenkins EK, Haines-Saah RJ, Daly Z, Jiao S. "You can't chain a dog to a porch": a multisite qualitative analysis of youth narratives of parental approaches to substance use. Harm Reduct J 2019; 16(1):26.

32. Bruns BL, J. Great Teachers: How to Raise Student Learning in Latin America and the Caribbean. Washington DC: International Bank for Reconstruction and Development / The World Bank; 2015.

Article submitted 21/01/2020

Approved 28/05/2020

Final version submitted 30/05/2020

Chief editors: Romeu Gomes, Antônio Augusto Moura da Silva 